\title{
Rediscovering lost relationships: Canadian Arctic ethnographic materials recovered from the 'ghost ship' Baychimo and the University of Alaska Museum of the North
}

\author{
Joshua D. Reuther
}

University of Alaska Museum of the North and Department of Anthropology, University of Alaska Fairbanks, 907 Yukon Drive, Fairbanks, AK 99775, USA. (jreuther@alaska.edu)

\author{
Jason S. Rogers \\ Northern Land Use Research Alaska, LLC, 1225 East International Airport Road, Suite 222, \\ Anchorage, AK 99518, USA.
}

Received January 2016; first published online 7 March 2016

\begin{abstract}
In 1931, the Hudson's Bay Company cargo steamer, SS Baychimo, was trapped in sea ice and abandoned in the Chukchi Sea off the northern coast of Alaska. Large amounts of scientific and navigational instruments and gear and personal items were left aboard, among them an ethnographic collection gathered in 1930 from Inuit groups in the Canadian Arctic by Richard Sterling Finnie. The ship was boarded several times over the next three years with items being salvaged by locals from nearby Wainwright and Barrow. In 1933, crew and passengers from MS Trader, a small trading vessel from Nome, boarded the abandoned ship and recovered several of Finnie's ethnological specimens. In 1934, Peter Palsson, crewmember of Trader, gave several ethnological specimens to members of the United States Department of the Interior-Alaska College Archaeological Expedition. That year, the Baychimo collection was accessioned to the nascent University of Alaska Museum (now, the University of Alaska Museum of the North). For over 80 years, the collection's relationships with Finnie, the Baychimo, and Palsson remained obscure, and its historical significance has just been rediscovered. This paper describes the collection and the path it took from the Baychimo to the University of Alaska Museum.
\end{abstract}

\section{Introduction: discovery of materials at UAMN}

In 1934, a small collection of ethnographic artifacts from the Canadian Arctic was added to the University of Alaska Museum (now, the University of Alaska Museum of the North [UAMN]) collections by Otto William Geist, the notorious collector and naturalist. The collection was given the accession number of Acc. 514, and placed in boxes labeled From Canadian Arctic taken from the 'Beychimo.' In the UAMN's early days, archaeological and ethnological specimens were grouped into a single anthropological collection, and differentiation between the two was not made until the early 1960s when the Archaeology and the Ethnology and History Departments became distinct entities within the museum. The ethnographic artifacts under Acc. 514 were placed into the archaeological collections after the establishment of the two departments. The assemblage remained there for 81 years with no recognition of its historical importance or its relationship to the abandoned Hudson's Bay Company cargo steamer, SS Baychimo (Fig. 1), the legendary abandoned vessel that floated in the Beaufort Sea icepack for over 30 years (Dalton 2006; Norton and Graves Gaylord 2004).

In October 2015, we were combing through UAMN's archaeological collections for materials to photograph to promote a forthcoming class in circumpolar archaeology. In a drawer simply labeled Acc. 514 Canadian Arctic was a group of artifacts typical of early $20^{\text {th }}$ century ethnological specimens indicative of Copper Inuit and Netsilik groups. As the boxes were marked Taken from the 'Beychimo,' we began to wonder if these articles could have been taken from Baychimo, the infamous 'ghost ship,' an abandoned icebound vessel said to make occasional appearances for over 30 years in the Alaskan Chukchi and Beaufort Sea region.

In this paper, we describe the collection (herein, referred to as the 'Baychimo collection'), how it was acquired by the UAMN, and our reasoning for assigning it to ethnographic materials that were left on Baychimo in 1930 by Richard Sterling Finnie, the Canadian explorer and documentary filmmaker.

A handwritten ledger for UAMN accessions from the 1930 s to 1950 s describes the collection as a gift from a Peter Balssan, acquired by Geist in 1934. No address or other details were provided for Mr. Balssan. The only provenance description for these artifacts is similar to those on the collection boxes: From the 'Beychimo' artifacts from the Canadian Arctic. When we began researching the origin and provenance of this collection, we assumed it was from an archaeological site, given that it was accessioned to the collections of the UAMN Archaeology Department.

An extensive literature and archival search for any mention of an archaeological site excavated in or prior to 1934 named 'Beychimo' or associated with the donor 'Peter Balssan' was unfruitful. However, we found recurring references associating Geist, in northern Alaska in the 1930s, to a Peter Palsson. Palsson was a crew member of MS Trader, a small wooden trading vessel owned by Ira Rank and the U.S. Mercantile Company in Nome, 


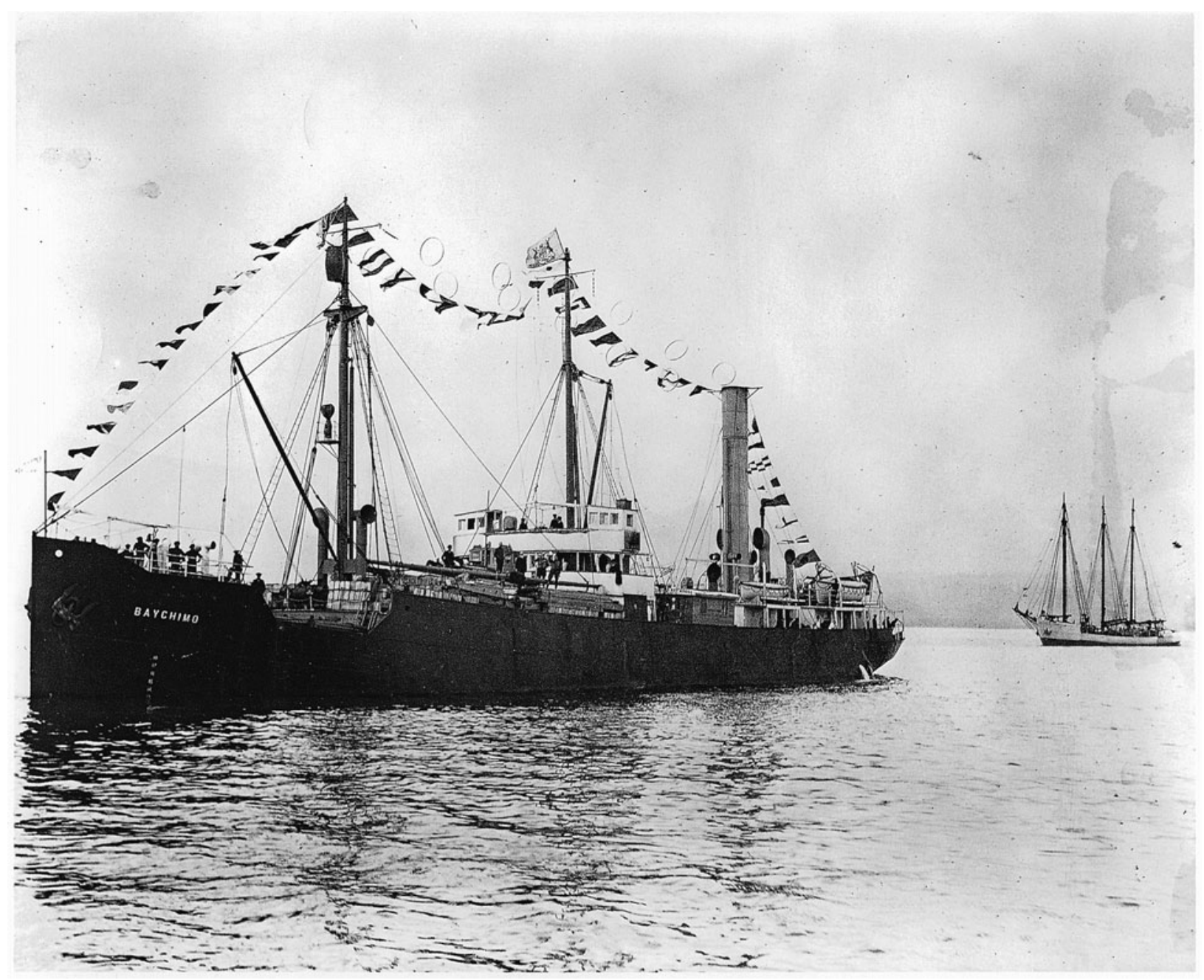

Fig. 1. The Hudson's Bay Company steamer, the Baychimo; photo taken by Captain George E. Mack between 19101926. (Photograph MP-0000.597.443 from the McCord Museum, Montreal, Quebec, Canada).

and was one of the last people known to have boarded Baychimo. It is highly likely that both Baychimo and Peter Palsson's names were misspelled in the accessions ledger, written at least 16 years after the donation of the materials to Geist. Below, we provide our reconstruction of the events and path that the Baychimo collections took from the acquisition of the materials by Finnie in 19301931 from a Canadian Arctic Inuit group or groups, to their procurement by Palsson in 1933, and, finally, their being donated to the UAMN through Geist in 1934.

\section{Richard Finnie's ethnographic collections and SS Baychimo}

In the summer of 1930, the Canadian Department of the Interior commissioned filmmaker and photographer Richard Finnie to spend a year in Canada's western Arctic as a Special Investigator (Fig. 2).

Finnie's main objective at this time was to document as much as possible of the 'pristine' culture and ways of life of the Copper Eskimos that had yet to be transformed by Euro-American contact (Geller 1996). Finnie initially traveled north down the Mackenzie River to the Arctic
Ocean, arriving at Herschel Island in late July 1930. After a short stay at Herschel, Finnie embarked on the Hudson's Bay Company supply ship SS Baychimo, which was delivering provisions to trading posts in Coronation Gulf and as far east as Cambridge Bay (Fig. 3).

Finnie left Baychimo in late August at Cambridge Bay, and spent the next year exploring and traveling to various western Arctic destinations, including a pioneering flight over the north magnetic pole. During this period Finnie acquired a large collection of ethnological artifacts and specimens from around Coronation Gulf, intended for the ethnographic department at the Canadian National Museum in Ottawa. Finnie left the collections, along with a large amount of personal gear (eight crates in all), at Fort Hearne, at the mouth of the Coppermine River. These were intended for shipment back to Vancouver during Baychimo's 1931 supply run (Finnie 1940). Finnie went on to make several photographic and film documentaries about the life in northern Canada, including the documentary film on the Copper Inuit made during the 1930-1931 trip, Among the Igloo dwellers (Geller 1996). His depictions of the early industrial development of the 


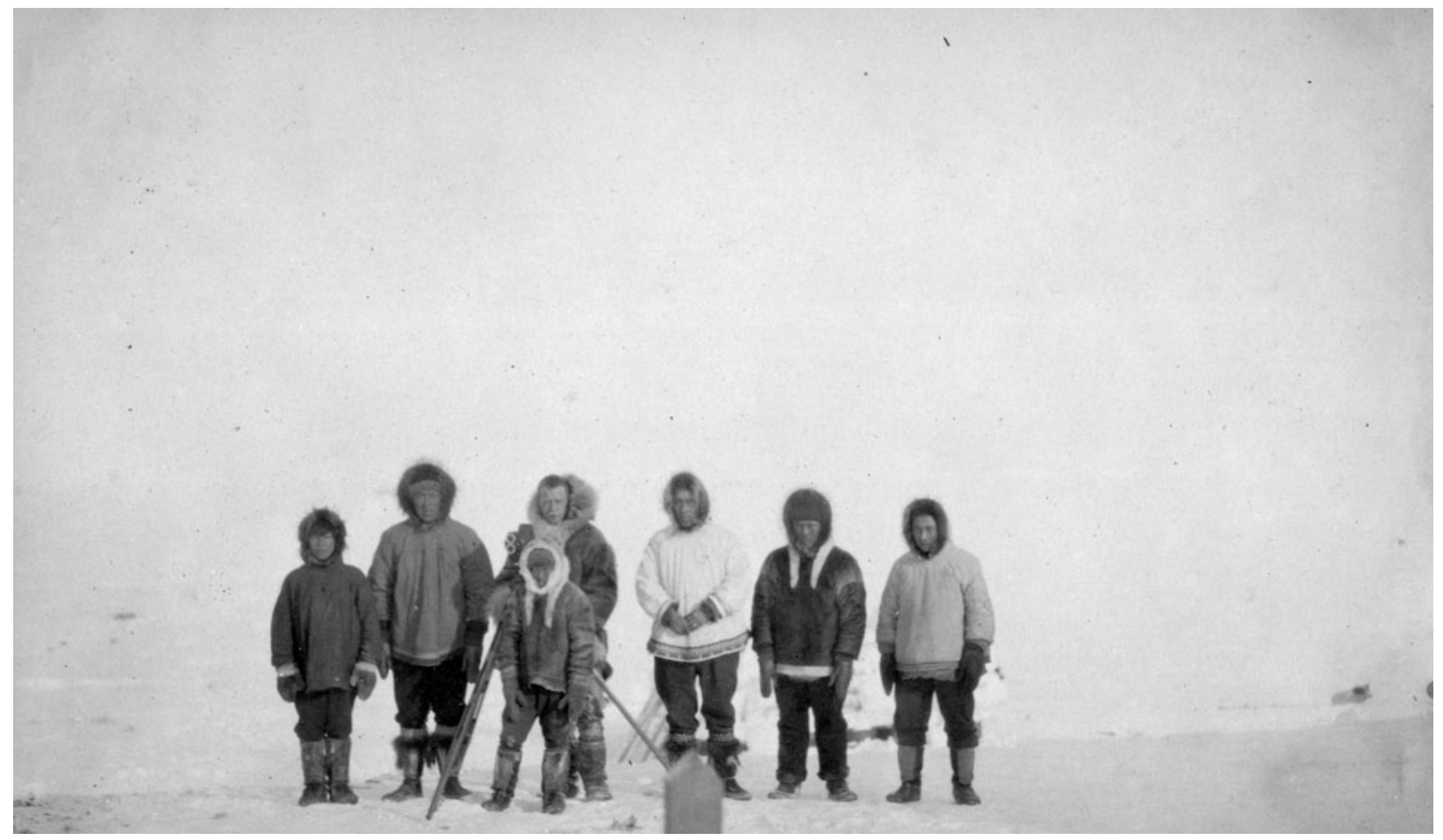

Fig. 2. Richard Finnie with Inuit actors from his film Among the Igloo Dwellers, in Tikeraq, Coronation Gulf, Nunavut, April 1931. (Photograph 1987-154 in the Richard Sterling Finnie Collection at Library and Archives Canada).

north and the intermingling of Inuit and Euro-American cultures made his work unique among his contemporaries and a pioneer in early film documentary in northern Canada.

\section{Trapped in ice}

Sea ice conditions in the summer of 1931 were difficult. Traveling east, Baychimo only rounded Point Barrow on 22 August, the latest she had ever entered the Beaufort Sea on her annual run to Coronation Gulf. Baychimo arrived at Fort Hearne on 5 September and spent four days offloading supplies and taking on cargo, including the eight crates of Richard Finnie's personal gear and ethnological specimens. Finnie himself had flown back to Ottawa earlier in the summer.

Outward-bound Baychimo passed Point Barrow traveling southwest on 18 September after difficult navigation through thick ice in the Beaufort Sea. The captain and crew were optimistic for a clear passage to Bering Strait. However, conditions in the Chukchi Sea had rapidly worsened as well, and by 25 September Baychimo was locked in ice in Peard Bay near Franklin Point (Dalton 2006; Norton and Graves Gaylord 2004) (Fig. 4).

By mid-October it was clear that the vessel was trapped and the decision was made to abandon ship. The majority of passengers and crew were evacuated by air to Nome (Fig. 4). A small contingent built a shore camp and prepared to wait through the winter and keep watch on the vessel. After a late November storm, the ship vanished and the shore crew assumed she had sunk (Dalton 2006).
However, in early December, the abandoned Baychimo was spotted by Iñupiat hunters and trappers near Skull Cliff, south of Barrow. They salvaged several bales of furs from the vessel's hold, and notified the shore party. By February 1932, Baychimo had once again disappeared from sight, and the remaining shore party was evacuated by air to Kotzebue. In subsequent years, the vessel, locked and drifting with the pack ice, was spotted and occasionally boarded. Some cargo was retrieved, although she rarely appeared close to shore and transportation was difficult (Dalton 2006).

\section{MS Trader visits Baychimo}

On 11 August 1933, Baychimo was visited by the crew of MS Trader, while anchored off the village of Wainwright. On board Trader were Rank (the owner), the brothers Peter and Kari Palsson (the captain and mate), and British traveler Isobel Wylie Hutchison. The crew tied up to Baychimo and attempted to break free the abandoned vessel from the ice to tow it to a location where it could be salvaged (Dalton 2006). However, they were unsuccessful in this attempt as Baychimo was too large for the smaller vessel to break free from the ice pack. The crew nevertheless recovered several items from Baychimo.

Hutchison was visiting the Arctic with the ostensible goal of collecting Alaskan botanical specimens for the Royal Herbarium at Kew, recorded in her memoir North to the rime-ringed sun (Hutchinson 1937). This volume also records her acquisition of Copper Inuit parkas and artifacts 'from a sack of curios' aboard Baychimo 


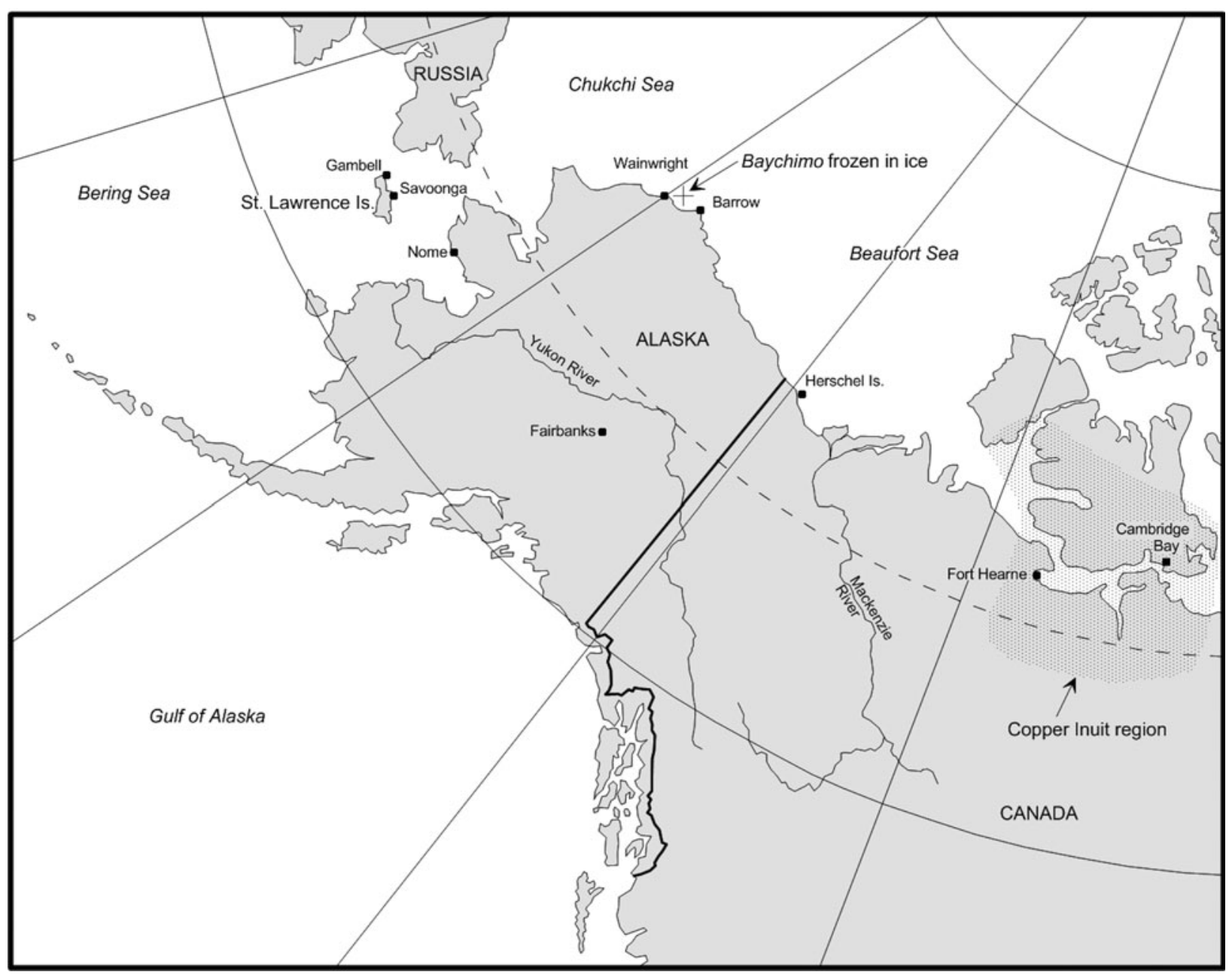

Fig. 3. Map of the western North American Arctic, showing locations mentioned in the text.

(Hutchison 1937: 110-115, 240). These specimens were subsequently donated to the Cambridge University $\mathrm{Mu}$ seum of Ethnology (now, the Museum of Archaeology and Anthropology). There is no doubt that these objects were part of Richard Finnie's ethnographic collections, for he later wrote:

One day I received a note from Charles Brower, veteran whaler and trader of Point Barrow, enclosing an old letter I recognized as having been in one of those cases on the derelict [Baychimo]. One of the local Eskimos who had been plundering the ship had handed it to him, and now he sent it along with the suggestion that I might like to have it as a souvenir. Still later, picking up a book written by an adventurous Englishwoman who had visited the Baychimo in the ice, what should catch my eye but a photograph of some Copper Eskimo costumes she had acquired for the Cambridge University Museum. I knew them well, these costumes, for they were part of the ethnological collection I had entrusted to the Baychimo (Finnie 1940: 47).

The UAMN artifacts described below were almost certainly recovered from Baychimo at the same time, either by Ira Rank or the Palsson brothers. The arti- facts were very likely taken directly from Baychimo, but we cannot exclude the possibility that they were also acquired from locals at Wainwright who had already salvaged several items from the vessel (Hutchison 1937: 110-115, 240).

\section{Description of materials}

The UAMN Baychimo collection is relatively small, numbering only 14 artifacts in total. These materials are characteristic of specimens from the early 20th century collected from the Copper and Netsilik Inuit in the Northwest Territories and Nunavut. We used several comparative collections from the Canadian Arctic to describe the Baychimo collection here, including: Steffanson (1914) materials in the American Museum of Natural History (see also AMNH 2015) that were collected between 1908 and 1912, and materials collected by Birket-Smith (1945) and others between 1908 and 1924, Diamond Jenness (1946) from 1914-1916, Noice between 1919-1921 (VanStone 1994), and Major Lachlan Taylor Burwash in 1925-1926 (Balikci 1984).

UA514-5245: Blubber pounder made of musk-ox horn (Fig. 5a). Length: $31 \mathrm{~cm}$. The pounding end has a 


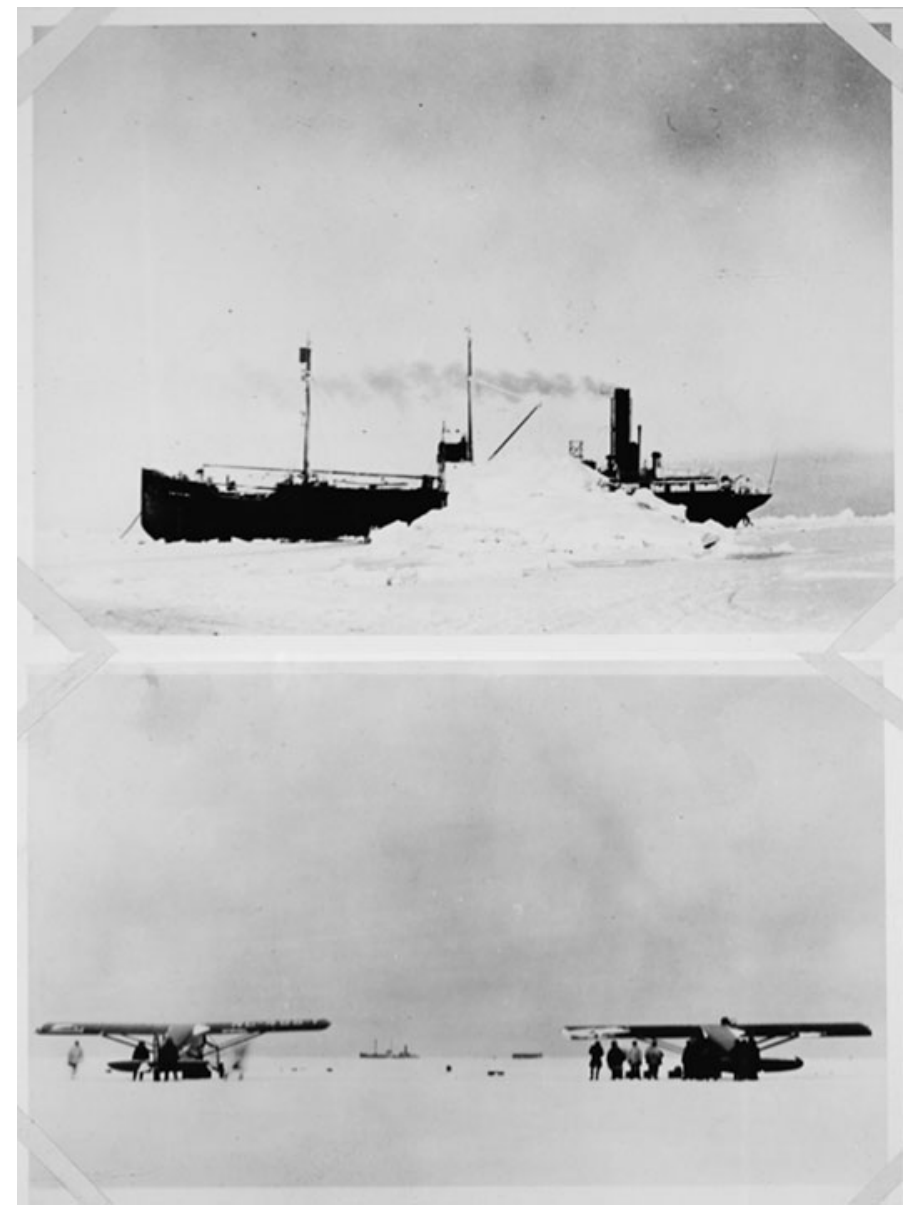

Fig. 4. Above: The SS Baychimo trapped in ice in Peard Bay off of Point Franklin, northern Alaska. Below: Aircraft landing in the winter of 1931 near Wainwright, Alaska, to rescue passengers and crewmembers of Baychimo (in the background). (Unpublished photographs from Garber 1936; UAF-2015-018100090 and UAF-2015-0181-00091, Alaska and Polar Regions Collections \& Archives at the Elmer E. Rasmuson Library).

flattened surface and the handle has four depressions or notches for fingers to grip the pounder. Similar pieces were collected from King William Island by Roald Amundsen in 1908 (Birket-Smith 1945: 90, 91), from the Coronation Gulf region by Stefansson (1914) in 1912, from Repulse Bay by Birket-Smith (1945: 90, 91), from Victoria Island by Noice between 1919-1921 (VanStone 1994: 14, Fig. 16d), and from Pelly Bay by Major Lachlan Taylor Burwash between 1925-1926 (Balikci 1984: Fig. 8). Balikci (1970: 63, 64) explains the use of the blubber pounder:

To provide fuel for the lamp, she extracted a piece of frozen blubber from the blubber bag and beat it with the blubber pounder on a board until it became soft and the oil liquefied..... The woman threw this dripping piece of blubber on the oil lamp.

UA514-5246: Copper ulu (commonly referred to as a 'woman's knife') with a caribou antler handle (Fig. 5b). Height: $12 \mathrm{~cm}$; width: $18 \mathrm{~cm}$. The blade edge is curved and the proximal end is tanged to slot into the handle.
The blade may be repurposed $1.4 \mathrm{~mm}$ thick copper sheet metal. Copper ulus were collected from Bernard Harbour by Jenness in 1914-1916 (see Damas 1984: Fig. 20), and Birket-Smith (1945: 203) between 1921 and 1924 from Prince Albert Sound. Other ulus that were collected by Noice (VanStone 1994: 12) at Victoria Island, and BirketSmith (1945: 203) and Stefansson (AMNH 2015: Catalog No. 60/6991 through 6998) in the Coronation Gulf region have iron blades, which when available likely replaced copper elements (Damas 1984: 413).

UA514-5247: Copper straight-edged knife (often referred to as a 'man's knife') with caribou antler handle (Fig. 5c). Length: $22.5 \mathrm{~cm}$. This knife has a slightly curved blade with a straight back. Its blade has a tang that is inset into the antler handle. The handle is curved at the proximal end where the bez or brow palm once extended from the main beam. Stefannson in 1912 (AMNH 2015: Catalog No. 60/6984) and Birket-Smith (1945: 203) between 1921 and 1924 collected iron knives of similar form from the Coronation Gulf area. 


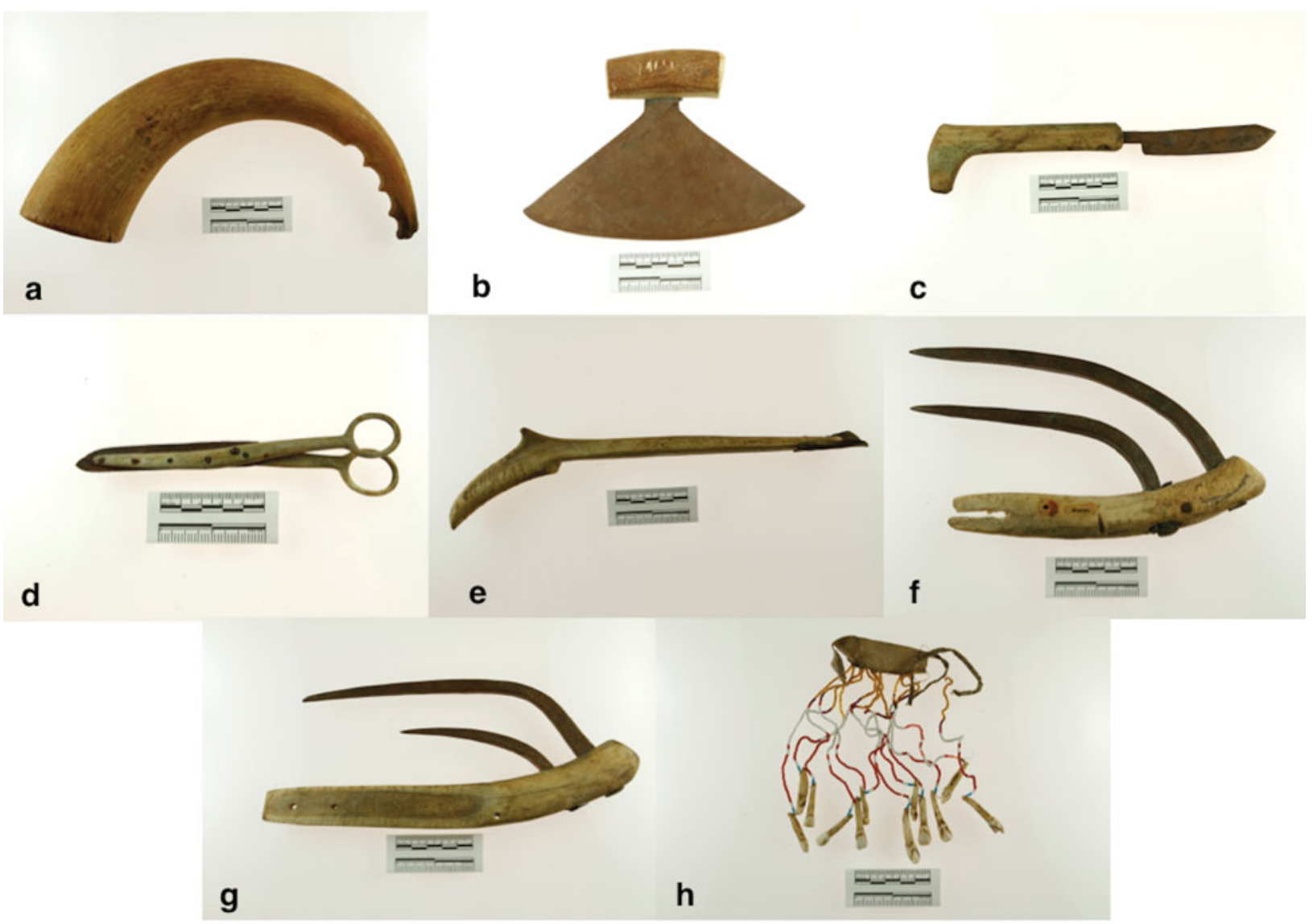

Fig. 5. UAMN Acc. 514 Baychimo collection specimens: (a) -5245, musk ox horn blubber pounder; (b) -5246, copper ulu; (c) -5247, copper men's knife; (d) -5248, scissors with antler handles; (e) -5249, skin scraper; (f-g) -5250 and -5251 , fish rakes; and (h) -5252 , item of personal adornment.

UA514-5248: Scissors with iron blades (Fig. 5d). Length: $17 \mathrm{~cm}$. The scissor handles are made of antler, and the iron sheet metal blades are attached to the handle with iron rivets. Similar scissors collected by Captain Joseph Bernard in 1915 at Cape Hamilton, N. W. T., are described by Damas (1984: Fig. 17):

The prototypes were acquired probably as early as the mid- $19^{\text {th }}$ century from Hudson Bay natives who got them through the Hudson's Bay Company and whalers (Jenness 1946: 96). Scissors were probably used for cutting hair and sewing.

Nearly identical specimens were also collected from King William Island by Amundsen (Birket-Smith 1945: 116) in 1908, and from the Coronation Gulf area by Stefansson (1914) in 1912 and Birket-Smith (1945: 212) between 1921 and 1924.

UA514-5249: Skin scraper blade made of copper and handle made from the main beam of a caribou antler (Fig. $5 e)$. Length: $30 \mathrm{~cm}$. The shaft of the beam was spilt from the inside curve opposite the rear point of the antler to the end of distal end of the handle. The presence of the rear point on the handle creates a 'fork' that prevents slippage of the hand during use (Jenness 1946: 83; VanStone 1994: 13). The copper blade is curved and riveted around the distal end of the handle. The blade shows indentations from the cold hammering process of shaping the blade. The proximal end of the handle is scored creating a rough texture. Nearly identical pieces were collected from Coronation Gulf by Stefansson (1914: Fig. 73) in 1912 and Birket-Smith (1945: 210, Fig. 180) between 1921-1924, Bernard Harbour by Jenness in 1914-1916 (as depicted in Damas 984: Fig. 20c), and the Victoria Island region by Noice between 1919 and1921 (VanStone 1994).

UA514-5250 and -5251: Fish rake heads (Figs. 5f and $5 \mathrm{~g}$ ). Two fish rake heads of similar construction. Lengths: $19.5 \mathrm{~cm}$ (UA514-5250) and $24.5 \mathrm{~cm}$ (UA5145251). These objects were originally categorised as Meat hook ? in the 1930s-1950s UAMN ledger. The hooks are fashioned from copper spikes that are inserted at the top of the head through holes in the antler. These copper spikes are typical of metal fastenings, repurposed into hooks, used in wooden boat and ship construction in the 19 th and early 20th centuries. Their principal use was in securing deck planking, and hull planking below the waterline. Copper (rather than iron) was used in these locations due to its corrosion resistance (Crothers 2000: 70). The spikes were 12 to $20 \mathrm{~cm}$ in length prior to being bent to form the hooks. Their cross-sections are rectangular with maximum thicknesses between 0.5 to 




Fig. 6. UAMN Acc. 514 Baychimo collection specimens: (a-e) -5253-1 through 5253-5 bone pins, and (f) -5254 leister side prong.

$1 \mathrm{~cm}$. Shims of copper were used to stabilise the hooks in the holes. The proximal end of the antler is split and holes have been drilled into the head for fastening to a handle. An iron rivet was used in one fish rake to repair the cracked head. Jenness collected a complete fish rake at Bernard Harbour between 1914-1916 (Damas 1984: Fig. 8) with a head similar to the UAMN specimens. The Jenness rake was lashed to a wooden handle. Damas (1984: Fig. 8) notes that these were 'used to catch arctic char. [...] Put under water and pulled up with a jerk, the rake usually caught several fish on the spikes at each pass.' Stefansson (1914: Fig. 29; AMNH Catalog No. 60/6972 A and B) also described similar objects collected from the Coronation Gulf in 1912.

UA514-5252: Personal adornment (Fig. 5h). The piece has a $6.5 \mathrm{~cm}$ long rectangular patch of hide that has 12 strands of seed beads hanging from it. Caribou incisors are attached to the ends of each strand, with the total height from the top of the hide rectangle to the incisors being $18 \mathrm{~cm}$. Thin strips of hide extend from the sides of the rectangular hide centre piece. The actual function of this piece is unclear, and we have had difficulty in finding similar items in the literature. The item potentially served as a brow band, hairpiece, part of a belt or amulet, but in any case it seems safe to refer to the piece as an item of personal adornment.
UA514-5253: Bone pins. These objects were originally categorised as Wound pin...Bone....6 lashed together in the 1930s-1950s UAMN ledger. There are six total objects represented under this catalog that are pin-like in form, however, only two are lashed together. Most of these objects are indicative of wound pins that were used to plug wounds in seals to stop bleeding so the animal could be more easily drug across ice (Kemp 1984: 467, Fig. 4).

UA514-5253-1 is a pin fashioned from sea mammal bone, and has a round tapering shaft with a head that curves to one side of the piece (Fig. 6a). Length: $1 \mathrm{~cm}$. The head is rounded at the top and flat on the bottom. A similar piece from Coronation Gulf is described by Birket-Smith (1945: 171, 172, Fig. 127) as a 'meat skewer.' Birket-Smith (1945: 171) explains that, '[a] bone skewer $[\ldots]$ prevents the animals viscera from falling out when the meat is to be carried after the hindquarters are separated from the rest.' Stefansson (AMNH 2015: Catalog No. 60.1/3270) also collected a similar item around Prince Albert Sound in 1912.

UA514-5253-2, -5253-3, and -5253-5 are three bone pins that have flat, rhombus-shape cross-sections (Figs. $6 \mathrm{~b}$ though $6 \mathrm{~d}$ ). Lengths: 12 to $14.5 \mathrm{~cm}$. Their heads are flat like a nail and the distal ends are flatter and more spatulate; their overall form is like a boat oar or paddle. 


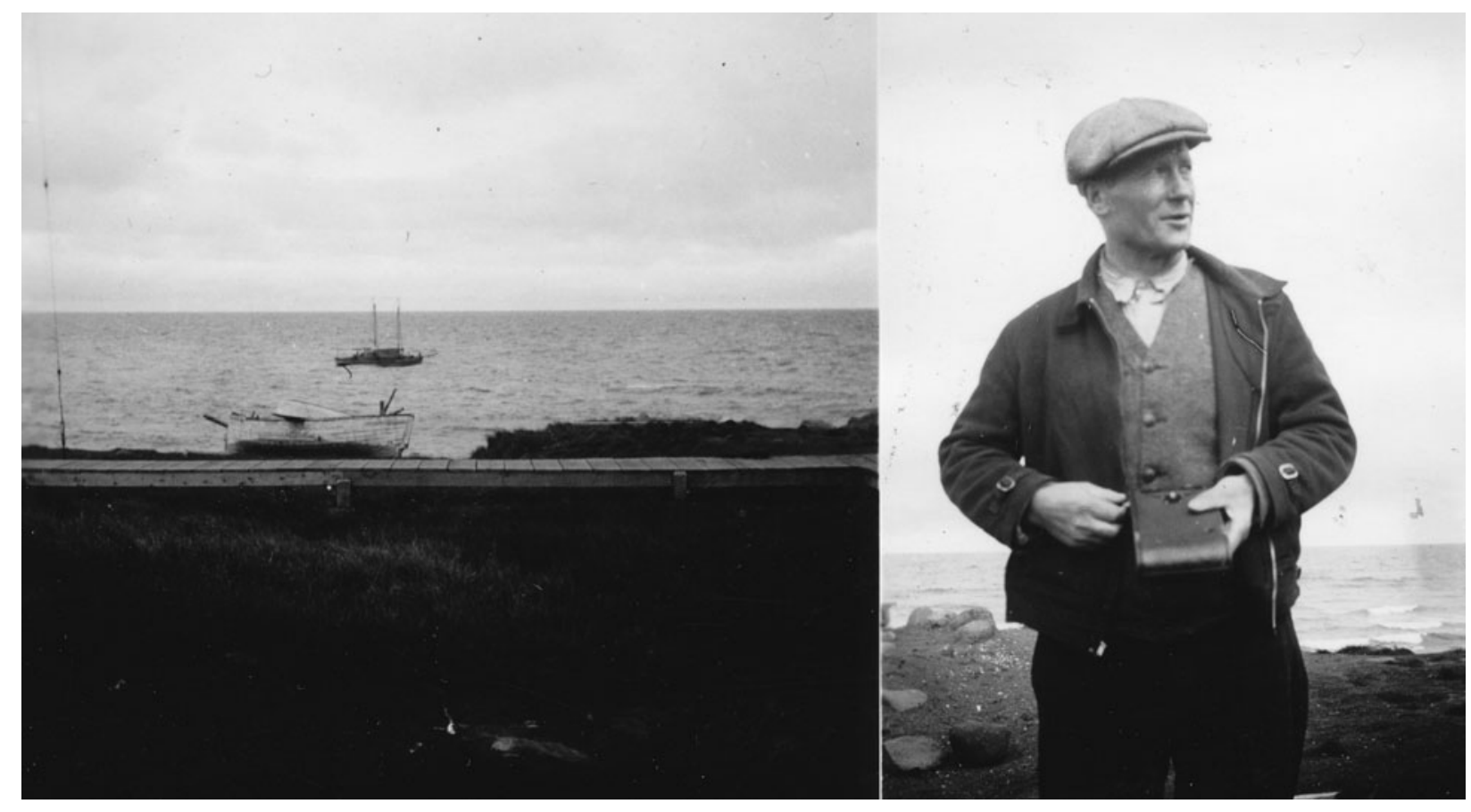

Fig. 7. Left: MS Trader arriving at St. Lawrence Island, 1939. Right: Pete Palsson, Captain of the Trader, St. Lawrence Island, 1939. (O.C. and Ruth Connelly photograph album, Archives and Special Collections, Consortium Library, University of Alaska Anchorage).

These objects are made of sea mammal bone. Stefansson (1914: Fig. 7) shows bone pins, which he refers to as wound pegs, set into a sheath of hide or fur, collected from the Coronation Gulf area between 1908 and 1912. AMNH (2015) also contains reference to a similar specimen (AMNH Catalog No. 60.1/3203 A-E) collected by Stefansson in 1912 from Lambert Island. Between 1921 and 1924, Birket-Smith (1945: 65, Fig. 27b) collected identical pieces from Depot Island, which he referred to as 'wound needles.'

UA514-5253-4 consists of two bone pins that have a nail-like form and are lashed together with hide (Fig. 6e). Length: $14 \mathrm{~cm}$. These pins have round tapering shafts and circular heads with round tops and flat undersides. Identical specimens were collected from Victoria Island between 1919 and 1921 by Noice and are described by VanStone (1994: Fig. 5f) as 'bones pins.' In 1912, Stefansson also collected several similar specimens from Kent Peninsula AMNH 2015: Cata$\log$ No. 60/6939R; Stefansson 1914, Fig. 39), Lambert Island (AMNH 2015: Catalog Nos. 60.1/3201 and No. 60.1/3202), and the greater Coronation Gulf region (AMNH 2015: Catalog No. 60/7033 AB; Stefansson 1914, Fig. 63). Stefansson (1914) noted that these were often carried with other items in a 'tool bag' that was attached to a bow case. He often referred to them as skewers or wound pins.

UA514-5254: Leister side-prong with barbs along the sides (Fig. 6f). Length: $39.5 \mathrm{~cm}$. This object was originally categorised as Fish spear prong? in the UAMN ledger. The barbs alternate in position along each side of the blade: 10 barbs on one side, 11 on the other side. The proximal end is spliced flat on its inner side to set and lash against the shaft of the leister, and a knob is present on the outer side to constrain movement of the lashing. VanStone (1994: 12) describes two types of leister configurations from this region based on specimens from the Victoria Island region collected by Noice between 1919 and 1921, one of which has identical barbed side prongs.

\section{A Gift to the UAMN}

Beginning in 1926, President Charles Bunnell of the Alaska Agricultural College and School of Mines (now the University of Alaska at Fairbanks) had sponsored archaeological and ethnographic collecting by Otto William Geist in the Being Sea region, which led to the Bunnell-Geist Bering Sea Expedition between 1927-1929 (Geist and Rainey 1936). After 1929, he led the Alaska Bering Sea Expedition (1931-1933) and the United States Department of the Interior-Alaska College Archaeological Expedition (1934-1935). As part of these expeditions, Geist and his crews surveyed, tested and excavated at several sites on St. Lawrence Island and other surrounding islands. They conducted one of the largest excavations in Alaska to date at the Kukulik site near Savoonga.

From 1933 to 1937, Geist was in frequent contact with Rank and Palsson, as his crews regularly traveled to Gambell and Savoonga, St. Lawrence Island, from Nome on Trader (Geist 1933-1937; Keim 1969), and purchased supplies from Rank's U.S. Mercantile Company (Fig. 7). 
The boarding of Baychimo by the Trader crew occurred on 11 August 1933. They left Isobel Wylie Hutchison at Barrow on 9 September (Hutchison 1937; Masik and Hutchison 1935). In 1933, Geist and his crew left Savoonga on the United States Coast Guard cutter Northland on 23 September, and were waylaid in Nome for a month due to weather (Geist and Rainey 1936: 47). We are uncertain if Trader reached Nome by the time of Geist's departure in October 1933. However, we have no reason to believe that the Baychimo collection was given to Geist during this time, and not in 1934 as stated in the UAMN ledger.

On 11 July 1934, Geist inquired to Nome Harbor Lighterage, U.S. Mercantile, and Lomen Commercial Companies for a price estimate to transport eight people and baggage, including an umiak skin boat, from Nome to Savoonga (Geist 1934a). On 17 July, the crew had to split into two groups to be transported to Savoonga due to a lack of space for all of the members and cargo on the available vessel (Geist 1934b; Geist and Rainey 1936: 49). Geist and three crewmembers took transport on a Northern Air Transport floatplane, landing at a lake near the village of Gambell (Geist 1935a; 1935b). The other four members and cargo were transported to Savoonga on a 'small trading vessel' (Geist and Rainey 1936: 49).

An accounting report for the 1934 United States Department of the Interior-Alaska College Archaeological Expedition field season (Geist 1935a) shows that on 1718 July 1934, a U.S. Mercantile Company boat (which we assume is Trader), transported part of the crew and baggage from Nome to Savoonga for \$200. Geist and his crew left Savoonga on Northland on 30 September 1934. While Trader may have transported dried fish, mail and other goods to St. Lawrence Island for the Expedition, there were no other records of the vessel transporting Geist or crewmembers in 1934, beyond 17 July when they transported part of the crew. We surmise that on 17 July 1934, during Trader's voyage to Savoonga, that Palsson gave one of Geist's crew the ethnographic materials from Baychimo. Geist subsequently deposited the artifacts at the nascent University of Alaska Museum in Fairbanks.

\section{Epilogue}

The UAMN Baychimo collection represents ethnographic materials collected from the Copper Inuit and Netsilik groups of the Northwest Territories and Nunavut in the Canadian Arctic. Richard Sterling Finnie collected the materials in 1930 for the Canadian National Museum in Ottawa. This was a period of major cultural and social transitions in Arctic communities, with increasing industrial resource exploitation and at the tail end of the heyday of northern scientific expeditions. Several researchers and explorers made extensive collections from the Copper and Netsilik Inuit groups prior to Finnie's trip. In and of themselves, the objects in the UAMN Baychimo collection do not contain great revelations about Copper and Netsilik Inuit groups, as many of the types of artifacts are represented in the earlier collections of Birket-Smith, Burwash, Jenness, Noice, and Stefansson, as noted above.

The historical significance of the UAMN Baychimo collection lies in the chain of linked relationships between Richard Finnie, legendary Baychimo, Peter Palsson and the crew of Trader, Isobel Wylie Hutchison, and finally Otto Geist and the United States Department of the Interior-Alaska College Archaeological Expedition. The fate of Baychimo is unclear, but it most likely eventually succumbed to the ravages of the sea ice and the Arctic Ocean. We are aware of only one other institution that has Finnie's ethnographic materials from Baychimo: the collection made by Hutchison and donated to the Cambridge University Museum of Ethnology (now, the Museum of Archaeology and Anthropology). The addition of these newly-revealed materials from the Baychimo collection provides a remarkable story of historical congruence during the early 20th century Arctic explorations. It brings these 80 year-old ethnographic materials out of obscurity, and places them in a wealth of historical context with a revived contemporary meaning.

\section{Acknowledgements}

We would like to thank the following for support on this project: Fawn Carter at UAMN for photography of the Baychimo collection, Dave Norton for his discussions on Arctic exploration and Baychimo, Angela Linn for insight on the history of the UAMN. The staff at the Alaska and Polar Regions Collections and Archives at the Elmer E. Rasmuson Library at University of Alaska Fairbanks for aide and expertise while we were combing through the Otto William Geist collections. Comments from Evguenia Anichtchenko and two anonymous reviewers greatly improved the manuscript.

\section{References}

Balikci, A. 1970. The Netsilik Eskimo. Garden City, New York: Natural History Press.

Balikci, A. 1984. Netsilik. In: Damas, D. (editor). Handbook of North American Indians, Vol. 5: Arctic. Washington D.C.: Smithsonian Institution: 415-430.

Birket-Smith, K. 1945. Ethnological collections from the Northwest Passage. Report of the Fifth Thule Expedition, 19211924, Vol. 6, No. 2. Copenhagen: Gyldendalske Boghandel Nordisk Forlag.

Crothers, W. 2000. The American-built clipper ship: characteristics, construction, details. Camden, ME: International Marine.

Dalton, A. 2006. Baychimo, Arctic ghost ship. Vancouver: Heritage House Publishing.

Damas, D. 1984. Copper Eskimo. In: Damas, D. (editor). Handbook of North American Indians, volume 5: Arctic. Washington D.C.: Smithsonian Institution: 397-414.

Finnie, R.S. 1940. Lure of the north. Philadelphia: David McKay Co.

Garber, C.H. 1936. Atanak, the white Eskimo: a true story of Alaska, as told to by Edward R Johnson. Unpublished manuscript (UAF-2015-0181). Fairbanks: Alaska and Polar Regions Collections \& Archives, Elmer E. Rasmuson Library, University of Alaska Fairbanks. 
Geller, P. 1996. Visions of a northern nation: Richard Finnie's views of natives and development in Canada's 'last frontier.' Film History 8: 18-43.

Geist, O.W. 1933-1937. Correspondence with Ira Rank, U.S. Mercantile Company. Otto W. Geist Collection, 19271963. Fairbanks: Alaska and Polar Regions Collections \& Archives, Elmer E. Rasmuson Library, University of Alaska Fairbanks.

Geist, O.W. 1934a. Letter to Nome Harbor Lighterage Co., 11 July 1934. Otto W. Geist Collection, 1927-1963. Fairbanks: Alaska and Polar Regions Collections \& Archives, Elmer E. Rasmuson Library, University of Alaska Fairbanks.

Geist, O.W. 1934b. Letter to Emil E. Hurja, 24 July 1934. Otto W. Geist Collection, 1927-1963. Fairbanks: Alaska and Polar Regions Collections \& Archives, Elmer E. Rasmuson Library, University of Alaska Fairbanks.

Geist, O.W. 1935a. Accounting report for the 1934 field season of the United States Department of the Interior-Alaska College Archaeological Expedition. Otto W. Geist Collection, 19271963. Fairbanks: Alaska and Polar Regions Collections \& Archives, Elmer E. Rasmuson Library, University of Alaska Fairbanks.

Geist, O.W. 1935b. First flight to St. Lawrence Island, Alaska. Geographical Record 25(3): 488-511.

Geist, O.W. and F. Rainey. 1936. Archaeological excavations at Kukulik, St. Lawrence Island, Alaska - preliminary report. Washington D.C.: U.S. Government Printing Office.
Hutchison, I.W. 1937. North to the rime-ringed sun, an Alaskan journey. New York: Hillman-Curl, Inc.

Jenness, D. 1946. The material culture of the Copper Eskimo. Report of the Canadian Arctic Expedition 1913-1918, Volume 16. Ottawa: Edmond Cloutier, King's Printer and Controller of Stationery.

Keim, C.J. 1969. Aghvook, white Eskimo: Otto Geist and Alaskan archaeology. Fairbanks: University of Alaska Press.

Kemp, W.B. 1984. Baffin Island Eskimo. In: Damas, D. (editor). Handbook of North American Indians, Vol. 5: Arctic. Washington D.C.: Smithsonian Institution, U.S. Government Printing Office: 463-475.

Masik, A. and I.W. Hutchison. 1935. Arctic nights' entertainments: being the narrative of an Alaskan-Estonian digger, August Masik at told to Isobel Wylie Hutchison during the Arctic night of 1933-1934 near Martin Point, Alaska. London: Blackie \& Son Limited.

Norton, D.W. and A. Graves Gaylord. 2004. Drift velocities of ice floes in Alaska's Northern Chukchi Sea flaw zone: determinants of success by spring subsistence whalers in 2000 and 2001. Arctic 57 (4): 347-362.

Stefánsson, V. 1914. The Stefansson-Anderson Arctic Expedition of the American Museum: preliminary ethnological report. Anthropological Papers of the American Museum of Natural History, Vol. XIV, Part I.

VanStone, J. 1994. The Noice collection of Copper Inuit material culture. Fieldiana, N.S. 20: 1-71. 